\title{
Computer-Assisted Teaching and Learning among Special Education Teachers
}

\author{
Safani Bari ${ }^{1}$, Mohd Hanafi Mohd Yasin ${ }^{1} \&$ Mussidiq Mohd Ramli ${ }^{1}$ \\ ${ }^{1}$ Faculty of Education, Universiti Kebangsaan Malaysia, Selangor, Malaysia \\ Correspondence: Safani Bari, Faculty of Education, Universiti Kebangsaan Malaysia, 43600 UKM Bangi, \\ Selangor, Malaysia. Tel: 60-3-8921-6398. E-mail: eda@ukm.my
}

Received: August 16, 2013

Accepted: October 14, 2013 Online Published: November 28, 2013

doi:10.5539/ass.v9n16p87

URL: http://dx.doi.org/10.5539/ass.v9n16p87

\begin{abstract}
Computer-assisted teaching and learning is an important concept that should be incorporated and applied by each special education teacher in the teaching and learning activities to make learning fun and interactive. Application of this method towards students with special needs is not widely used compared to other typical students. Therefore, in order to determine how far the method is practiced by special education teachers, a survey is conducted. The respondents consisted of 89 special education teachers in Klang district which involved in 16 elementary schools that offer integrated special education programs. The data obtained from the questionnaire, which has been adapted from the previous studies were then analyzed by using Statistical Package for Social Science (SPSS) version 20 and the results were discussed in a form of descriptive analysis including analysis of the percentage. In addition, the summary of the final data was done based on the percentage and the mean indicated. The result of the study showed that special education teachers in Klang district understand the concept of Computer-Assisted Teaching and Learning. However, there were constraints in implementing the method in teaching and learning. Adequate training should be given to special education teachers in order to improve the quality of teaching as well as to produce skilled and competent teachers in dealing with information technology's equipment. In relation to this, the results of this research can be used as a guide to empower Computer-Assisted Teaching and Learning in Integrated Special Education Program.
\end{abstract}

Keywords: computer-assisted teaching and learning, implementation, constraints, special education

\section{Introduction}

Computer is a sophisticated and useful electronic device. Humans use it to manage documents and to surf the internet. As technology invented is getting more advanced by days, computer seems to be beneficial to be used in learning. In the era of globalization, computer is found to be suitable to assist special education teachers in teaching and learning process as it is able to receive and process data efficiently and effectively. Ishak Othman (2002) defined Computer-Assisted Teaching and Learning as softwares used in education and the practices are developed by programming languages, multimedia authoring and programming which are suitable to be used in teaching as well as learning a subject. There are some people who equate Computer-Assisted Teaching and Learning with courseware. According to Ahmad Rasidi Osman (1999), Computer-Assisted Teaching and Learning is the use of computer complement with a certain type of software to assist teachers in teaching and help students in learning. In a research context, Computer-Assisted Teaching and Learning is defined as the use of computers or other electronic device that will effectively help teachers to deliver the contents of a subject either fully or partially during teaching. For instance, Microsoft Power Point, Microsoft Access, Microsoft Word, Microsoft Publisher, Microsoft Excel, Microsoft Paint, AUTO CAD, Photoshop, and Flash.

A study conducted by Bahrudin, Mohammad Bilal and Muhammad Kasim (2001) shows that information and communication technology can help to overcome the shortcomings of science education that is taught traditionally through the involvement of teachers in using the computers productively. Roblyer and Schwier (2003) stated that the use of technology in education is able to increase productivity, motivation and information literacy, to provide a unique teaching ability as well as to support teaching and learning. The use of multimedia in teaching and learning process is believed regarding its effectiveness in helping teachers and students, Jamaluddin Harun and Zaidatun Tasir Jamaluddin (2003). It is supported by the evidence found in the results of 
a research by Khairul Anuar Abdul Rahman (2011), which shows the development of Computer-Assisted Teaching and Learning in education improves the understanding of students with special needs.

Throughout the modernization of technology, schools in Malaysia has taken steps in integrating the use of computers to conduct teaching and learning activities at all levels of school with the help of Ministry of Education (MOE). Special education schools and schools with Integrated Special Education Program have not been spared from the use of this technology. Esah Sulaiman (2003) states that, a variety of teaching and learning approaches can be used during teaching and learning, such as teacher-centred approach, student-centered approach or materials-centered approach. Teachers are responsible to choose the appropriate approach to be used in order to achieve the planned objectives for a lesson. Although the use of Computer-Assisted Teaching and Learning shows a positive impact on student's learning, there are constraints that need to be solved to ensure teachers are able to implement Computer-Assisted Teaching and Learning in school without a hitch, Yahya Othman (2007). He also states that, special education teachers should be prepared with adequate skills and knowledge in line with the current educational needs. Therefore, this study attempts to observe the level of understanding among special education teachers towards the concept of Computer-Assisted Teaching and Learning, teachers' level of computer proficiency, the impact of using a computer in teaching students with special needs and the constraints in implementing it.

\section{Problem Statement}

Schools across the country have been provided with computers by the government as an effort to increase teachers' professionalism. The government hopes that teachers in schools, especially special education teachers use the computer in teaching and learning process as a teaching aid in the classroom (Education Development Master Plan, 2006). The role played by special education teachers will determine the level of students' understanding in learning a subject. For this purpose, the use of various teaching techniques and different levels of practices which suit their abilities, experiences and interests should be taken into account. All the aspects mentioned are important to maintain students' attention as long as needed to master the content of certain subjects. It is important to know how far the teaching aid is beneficial for the teachers and students. The effectiveness of teaching aid is not only determined by the quality but also the techniques of using it in a classroom. If teachers fail to use teaching aid during a lesson effectively, this might cause the interaction between teachers and students become rather limited (Abu Hassan Kassim and Meor Ibrahim Kamaruddin, 2006). According to Syuhada Choo Abdullah (2005), Educational Technology Division (ETD), MOE will visit schools throughout the country to monitor and analyze the use of technology in education, especially the information and communication technology provided by the government. This is done because teachers refuse to use technology in teaching and learning process. In addition, ETD, MOE visits schools with the intention to know the actual progress of using technology and facilities supplied to schools in education.

Other factors that influence the use of Computer-Assisted Teaching and Learning is in terms of technical, teaching aid facilities, and attitude. Most teachers feel that it is difficult to change their learning style towards something new such as using Computer-Assisted Teaching and Learning in teaching. This problem occurs due to the teachers' attitude. A study conducted by Yahya Othman (2007) proved that the problem occurs because teachers feel in doubt with new ideas as they feel more comfortable with what they have done over the years. The Education Act (1996) states that teachers are allowed to modify the methods and techniques of teaching and learning, the time or duration of activities, the subjects and teaching aids to achieve the objective of Special Education.

There are studies showing that teachers rarely use the facilities provided by the government in teaching and learning process. William (2005) stated in his study that special education teachers do not have the skills of using teaching aids in teaching students with special needs. This condition will produce a weak special education teacher in terms of teaching as well as in conducting teaching aids. Based on these studies, it shows that there are still a lot of teachers that do not use teaching aids during their lessons. Therefore, one of the methods to perform this role is to promote the development of information and communication technology in schools which will bring benefits to support the teaching and learning process.

This is important because teaching and learning process should involve three main factors: teachers, curriculum content and students. These factors must be included in teaching and learning through several approaches, methods and techniques that are appropriate and well-planned, prepared and be carried out in order. Education is the place where information and communication technology should be used efficiently and effectively by teachers (Daud, 2006). 


\section{Research Questions}

This study will try to answer the following questions:

1) Do special education teachers understand the concept of computer-assisted teaching and learning?

2) What is the level of computer proficiency among special education teachers?

3) What are the effects of the use of computers in teaching students with special needs?

4) What are the constraints in the implementation of computer-assisted teaching and learning?

\section{Structure of Study}

This study is a descriptive quantitative survey using questionnaire adapted from previous studies. The data obtained consists of items related to teacher's demography, computer-assisted teaching and learning's concept, the level of computer proficiency among teachers, the impacts of using computer in teaching students with special needs and the constraints of implementing computer-assisted teaching and learning in education. The population sample consists of 177 people who are special education teachers in Klang district. Meanwhile, 89 people which covered $50 \%$ of the total population were randomly selected to be the sample of the study. The total of the sample is appropriate because, according to Mohamad Najib Abdul Ghafar (2003), the minimum amount for a selected sample is $30 \%$ of the total population. He also stated that, the larger the size of a sample, the better it will be because researchers have more possibility to choose the sample which has the characteristics of a population.

Table 1. Total population and sample of elementary schools' special education teachers in Klang District in 2012

\begin{tabular}{llll}
\hline Bil. & Schools & $*$ Population & Sample \\
\hline 1 & Klang Primary School & 11 & 5 \\
2 & Telok Gadong Primary School & 26 & 12 \\
3 & Taman Klang Jaya Primary School & 15 & 6 \\
4 & Pelabuhan Utara Primary School & 3 & 3 \\
5 & Sultan Abdul Samat Primary School & 14 & 6 \\
6 & Meru Jalan Tap Primary School & 3 & 3 \\
7 & Taman Klang Utama Primary School & 16 & 7 \\
8 & Meru 2 Primary School & 15 & 6 \\
9 & Bukit Kemuning Primary School & 3 & 3 \\
10 & Pulau Indah 2 Primary School & 3 & 3 \\
11 & Bukit Rimau Primary School & 13 & 6 \\
12 & Batu Unjur Primary School & 29 & 12 \\
13 & Bukit Ceraka Primary School & 3 & 3 \\
14 & Tengku Bendahara Aman (1) & 9 & 5 \\
15 & Tengku Bendahara Aman (2) & 3 & 3 \\
16 & Bukit Kuda Primary Girls School & 11 & 6 \\
& Total & $\mathbf{1 7 7}$ & $\mathbf{8 9}$ \\
\hline
\end{tabular}

*source Klang District Education's Office 2012

The data obtained was analyzed using the Statistical Package for the Social Sciences (SPSS) version 20.0 in the form of descriptive analysis by taking into account the mean and the percentage value. The schedule of level of evaluation which was constructed by Mohamed Najib Abdul Ghafar (2003) was used as a guide in determining the level based on the mean score. 
Table 2. Level of evaluation based on the mean score

\begin{tabular}{llllll}
\hline Level of Mean Score & Very Low & Low & Moderate & High & Very High \\
\hline Range of Mean Score & $1.00-1.49$ & $1.50-2.49$ & $2.50-3.49$ & $3.50-4.49$ & $4.50-5.00$ \\
\hline
\end{tabular}

\section{Results}

5.1 Demographic Information of Respondents

Table 3. Respondents' demographic information

\begin{tabular}{llll}
\hline Item & & Frequency & Percentage (\%) \\
\hline Gender & Male & 17 & 19.1 \\
Education & Female & 72 & 80.9 \\
& Master & 5 & 5.6 \\
& Bachelor & 66 & 74.2 \\
Experience & Diploma & 15 & 16.9 \\
& Certificate & 3 & 3.4 \\
& 1 to 5 years & 50 & 56.2 \\
& 6 to 10 years & 17 & 19.1 \\
& 11 to 15 years & 16 & 18.0 \\
\hline
\end{tabular}

$\mathrm{N}=89$

The results are obtained from a total of 89 respondents which consist of 17 males $(19.1 \%)$ and 72 females $(80.9 \%)$ who are the teachers of special education programs in Klang district. The study found that the majority of respondents are from the graduates which brings a total of $71(79.8 \%), 15(16.9 \%)$ who had a diploma and 3 (3.4\%) with a teaching certificate. The study also found that the majority of respondents have teaching experience in between 1 to 5 years of which as many as 53 people (59.6\%), followed by 20 respondents $(22.5 \%)$ who has 6 to 10 years of teaching experience, $15(16.9 \%)$ had between 11 to 15 years and one $(1.1 \%)$ have 16 years of experience in the field of special education.

\subsection{The Concept of Computer-Assisted Teaching and Learning}

The first research question is the level of understanding of the special education teachers in Klang district towards Computer-Assisted Teaching and Learning's concept. According to Table 4, there are 7 sub-questions in total.

Table 4.The concept of Computer-Assisted Teaching and Learning

\begin{tabular}{lll}
\hline Item & Mean & $\begin{array}{l}\text { Standard } \\
\text { deviation }\end{array}$ \\
\hline Students who learn a subject using computer in the presence of a teacher & 3.47 & 0.605 \\
Students who learn a subject using computer without the presence of a teacher & 1.74 & 0.594 \\
Students who use a search engine (e.g. Google) to find information while doing & 2.98 & 0.674 \\
exercises & & \\
Teachers who use the LCD projector as a teaching aid in parts of their teaching & 3.35 & 0.623 \\
Students who learn counting and writing using Microsoft Office Word & 2.73 & 0.719 \\
Students who learn by using educational software provided in a CD & 2.81 & 0.689 \\
Students who learn through a distance learning by using a computer & 2.20 & 0.756 \\
Average Mean & 2.75 & \\
\hline
\end{tabular}

$\mathrm{N}=89$ 
The average mean value for the concept of Computer-Assisted Teaching and Learning is 2.75 which means, special education teachers in Klang area have a moderate understanding of the concept. The results are also supported by the results of a study conducted by Yahya Othman, (2007).

\subsection{Teachers' Level of Computer Proficiency}

Table 5. Teachers' level of computer proficiency

\begin{tabular}{lll}
\hline Item & Mean & Standard deviation \\
\hline Mastering Microsoft Word & 3.56 & 0.639 \\
Mastering Microsoft Excel & 3.09 & 0.733 \\
Mastering Microsoft Access & 2.64 & 0.787 \\
Mastering Microsoft Power Point & 3.46 & 0.623 \\
Mastering Multimedia & 2.96 & 0.752 \\
Mastering Website's Construction & 2.43 & 0.865 \\
Mastering the Internet & 3.48 & 0.503 \\
Average Mean & $\mathbf{3 . 0 8}$ & \\
\hline
\end{tabular}

$\mathrm{N}=89$

The value of average mean score obtained for the variable level of computer proficiency among special education teacher is 3.08. Therefore, it can be defined based on the mean score rating table that the level of computer proficiency of Integrated Special Education Program's teachers in Klang district is moderate. This result is in contrast with the previous result of a study conducted by Zaidatun Nasir and Lim, B. Y., (2011) which states that the level of teachers' knowledge is moderately high and it is supported by a study conducted by Yusof Boon and Sani Ngatimin (2011). The difference that exists in the results between the researchers may be due to the study conducted, respondents' background and the influence of rapid technological development.

5.4 The Impacts of the Use of Computer towards Students with Special Needs

Table 6. The impacts of the use of computer towards students with special needs

\begin{tabular}{lll}
\hline Item & Mean & Standard Deviation \\
\hline $\begin{array}{l}\text { Does the use of computers in teaching increase the students' } \\
\text { interests in learning? }\end{array}$ & 3.66 & 0.475 \\
$\begin{array}{l}\text { Do excellent students become more interested to learn if teachers } \\
\text { use a computer in teaching? }\end{array}$ & 3.44 & 0.673 \\
$\begin{array}{l}\text { Do weak students become more interested to learn if teachers use a } \\
\text { computer in teaching? }\end{array}$ & 3.31 & 0.748 \\
$\begin{array}{l}\text { Does the use of multimedia and interactive materials would affect } \\
\text { the students? }\end{array}$ & 3.53 & 0.502 \\
$\begin{array}{l}\text { Do students become more interested to learn if materials from the } \\
\text { internet are used in teaching? }\end{array}$ & 3.47 & 0.502 \\
\begin{tabular}{l} 
Average Mean \\
\hline
\end{tabular} & $\mathbf{3 . 4 8}$ & \\
\hline
\end{tabular}

$\mathrm{N}=89$

Based on the results obtained, most of the special education teachers in Klang district agree with the concept of Computer-Assisted Teaching and Learning in education as it gives positive impacts to students with special needs. The average mean calculated is 3.48 which can be categorized in a higher level. This data is also supported by the results obtained from a study conducted by Yahya Othman, (2007) on the impact of the use of computer towards students with special needs. 


\subsection{The Constraints in Implementing Computer-Assisted Teaching and Learning in School}

The last question need to be answered in this study is if there are any constraints to implement Computer-Assisted Teaching and Learning in school. Table 7 shows the results that have been obtained for this question.

Table 7. The constraints in implementing computer-assisted teaching and learning in school

\begin{tabular}{|c|c|c|c|}
\hline Item & Scale & Frequency & $\%$ \\
\hline \multirow[t]{4}{*}{ Teachers are not proficient because they lack of training? } & Strongly disagree & 6 & 6.7 \\
\hline & Disagree & 18 & 20.2 \\
\hline & Agree & 52 & 58.4 \\
\hline & Strongly agree & 13 & 14.6 \\
\hline \multirow{4}{*}{$\begin{array}{l}\text { Preparing materials for Computer-Assisted Teaching and } \\
\text { Learning takes a lot of time? }\end{array}$} & Strongly disagree & 2 & 2.2 \\
\hline & Disagree & 24 & 27.0 \\
\hline & Agree & 47 & 52.8 \\
\hline & Strongly agree & 16 & 18.0 \\
\hline \multirow{4}{*}{$\begin{array}{l}\text { Preparing the device to carry out Computer-Assisted Teaching } \\
\text { and Learning in class takes a lot of time? }\end{array}$} & Strongly disagree & 0 & 0.0 \\
\hline & Disagree & 31 & 34.8 \\
\hline & Agree & 45 & 50.6 \\
\hline & Strongly agree & 13 & 14.6 \\
\hline \multirow[t]{4}{*}{ Computers in schools are under good maintenance? } & Strongly disagree & 23 & 25.8 \\
\hline & Disagree & 28 & 31.5 \\
\hline & Agree & 33 & 37.1 \\
\hline & Strongly agree & 5 & 5.6 \\
\hline \multirow{4}{*}{$\begin{array}{l}\text { Computers in schools are often under faulty and the capacity } \\
\text { and technology used are outdated? }\end{array}$} & Strongly disagree & 10 & 11.2 \\
\hline & Disagree & 22 & 24.7 \\
\hline & Agree & 40 & 44.9 \\
\hline & Strongly agree & 17 & 19.1 \\
\hline \multirow{4}{*}{$\begin{array}{l}\text { Do school administrators encourage teachers to use } \\
\text { Computer-Assisted Teaching and Learning in class? }\end{array}$} & Strongly disagree & 3 & 3.4 \\
\hline & Disagree & 6 & 6.7 \\
\hline & Agree & 59 & 66.3 \\
\hline & Strongly agree & 21 & 23.6 \\
\hline \multirow{4}{*}{$\begin{array}{l}\text { Are the equipments adequate to implement Computer-Assisted } \\
\text { Teaching and Learning in class? }\end{array}$} & Strongly disagree & 15 & 16.9 \\
\hline & Disagree & 39 & 43.8 \\
\hline & Agree & 30 & 33.7 \\
\hline & Strongly agree & 5 & 5.6 \\
\hline
\end{tabular}

$\mathrm{N}=89$

Based on Table 7, 52 (58.4\%) respondents agreed that one of the constraints in the implementation of Computer-Assisted Teaching and Learning in schools is teachers are unskilled due to lack of training in implementing Computer-Assisted Teaching and Learning. Respondents also agreed (52.8\%) on the preparation of materials for Computer-Assisted Teaching and Learning takes a long time. 33 respondents (37.1\%) said the computers provided in their schools are well-maintained, 5 respondents $(5.6 \%)$ strongly agreed, $28(31.5 \%)$ disagreed and the remaining $23(25.8 \%)$ strongly disagreed with the statement. $44.9 \%$ or 40 people out of 89 respondents agreed to computers in schools are outdated in terms of capacity and technology. The majority of 
respondents agreed that school administrators give encouragement to them to implement Computer-Assisted Teaching and Learning in class. However, the majority of respondents disagreed with the statement that the equipment used to carry out Computer-Assisted Teaching and Learning is adequate. The results of this study are supported by the results of the study conducted by Yahya Othman, (2007) and Siti Khadijah Ramly (2012).

\section{Suggestion}

The results have shown that special education teachers in Klang district agreed that the use of Computer-Assisted Teaching and Learning in education gives positive impacts on students with special needs. Thus, several proposals have been given to strengthen the use of Computer-Assisted Teaching and Learning among special education teachers. One of them is to provide an easy access to special education teachers to use the equipment for Computer-Assisted Teaching and Learning that has been provided for the typical students. It can be done if the learning sessions for students with special needs are also included in the timetable of using school computer lab. In addition, the ministry of education must ensure that all of the computer equipment supplied to schools must be maintained regularly and outdated equipment must be replaced.

In order to encourage teachers to practice Computer-Assisted Teaching and Learning in education is by making sure every classroom is equipped with multimedia equipment. This may lessen the time it takes to prepare the equipment for teaching and learning process. Teachers also need to be equipped with the latest knowledge by organizing Computer-Assisted Teaching and Learning courses which are appropriate with the type and the needs of every Integrated Special Education Program as students with special needs has different abilities. E-learning materials are based on Computer-Assisted Teaching and Learning which need to be prepared in 2 versions. The first version is for a typical student while the second version is adapted to the types of students with special needs. Thus, the time used to prepare the materials in teaching and learning process can be reduced. In fact, the quality of education by using Computer-Assisted Teaching and Learning will be guaranteed if the Ministry of Education elects a recognized body to provide the materials.

\section{Conclusion}

By referring to the results of this study, the questions proposed in this study have been answered and it can be concluded that special education teachers in Klang district have a moderate understanding of the concepts in Computer-Assisted Teaching and Learning. Special education teachers in Klang district also agreed to use the computer as a tool in teaching and learning as it gives a positive impact on the interest and understanding of students with special needs. In addition, there are constraints for teachers to implement Computer-Assisted Teaching and Learning in education for students with special needs. Meanwhile, school administrators always encourage and urge special education teachers to implement the method of learning and do not treat the method as a deterrent factor. Based on the results obtained, it can also be concluded that Computer-Assisted Teaching and learning is a method which is able to provide variation in learning towards students with special needs. Actually, students with special needs are more attracted to a different type of learning environment which helps to stimulate their level of understanding, and at the same time, Computer-Assisted Teaching and Learning offers a better way for teachers to make teaching and learning process fun and interactive despite achieving the objective of the subjects that are being taught.

\section{References}

Abdullah, S. C. (2005). Pengkomputeran khas seragam pengurusan SBPT. Berita Harian Publisher.

Aris, B., Bilal, M., \& Basir, M. K. (2001). Pembelajaran Fizik Secara Kolaboratif Menggunakan Laman Web dan Internet. Virtec Journal, 1(1).

Boon, Y., \& Ngatimin, S. (2011). Penggunaan Makmal Komputer dalam kalangan Guru-Guru Sekolah Kebangsaan Zon Jementah, Daerah Segamat Dalam Pengajaran dan Pembelajaran: Satu Tinjauan. Journal of Technical, Vocational \& Engineering Education, 3, 132-147.

Daud, A. R. (2006). Teknologi Pendidikan. Konsep, Peranan dan Perkembangan. Selangor Darul Ehsan: Sutera Publication.

Ghaffar, M. N. A. (2003). Reka Betuk Tinjauan Soal Selidik Pendidikan. Johor: Penerbit Universiti Teknologi Malaysia.

Harun, J., \& Tasir, Z. (2003). Asal multimedia dan aplikasinya dalam pendidikan. Bentong: PTS Publication.

Kassim, A. H., \& Kamaruddin, M. I. (2006). Ke arah Pengajaran Sains dan Matematik Berkesan. Universiti Teknologi Malaysia. 
Kementerian Pelajaran Malaysia. (1996). Akta Pendidikan 1996: Akta 550 Kementerian Pelajaran Malaysia (2006). Pelan Induk Pembangunan Pendidikan (PIPP). RMK-9

Osman, A. R. (1999). Penggunaan Komputer di kalangan guru-guru Sekolah Menengah Daerah Temerloh Pahang. Tesis Sarjana, Universiti Kebangsaan Malaysia, Malaysia.

Othman, M. I. (2002). Pembinaan pelajaran dan pembelajaran berbantukan computer: Belajar mengenai storan skunder. Projek Sarjana Pendidikan. Bangi: Universiti Kebangsaan Malaysia.

Othman, Y. (2007). Aplikasi Komputer Dalam Pengajaran Bahasa: Penguasaan Guru dan Kekangan Dalam pelaksanaan. $1^{\text {st }}$ International Malaysian Educational Technology Convention (47-54).

Rahman, K. A. A. (2011). Perisian matematik bagi tajuk pecahan untuk pelajar berkeperluan khas. Jurnal Teknologi Pendidikan Malaysia Jilid, 1(2).

Ramly, S. K. (2012). Penggunaan Teknologi Maklumat dan Komunikasi Guru-Guru Pendidikan Khas Bermasalah Pembelajaran. Seminar Internasional Pasca Siswazah Pendidikan Khas UKM-UPI Siri II 2012 (188-192).

Roblyer, M. D., \& Schwier, R. (2003). Integrating educational technology into teaching (Canadian ed.). Toronto: Prentice Hall.

Sulaiman, E. (2003). Asas pedagogi. Johor Bahru: Penerbit Universiti Teknologi Malaysia.

Tasir, Z., \& Lim, B. Y. (2011). Tahap Pengetahuan, Sikap Dan Masalah Penggunaan Komputer DI Kalangan Guru Di Sekolah Menengah Daerah Alor Gajah. Journal of Social Science, 3, 83-103.

William, E. E. (2005). Teaching the Mentally Handicapped Child: Challenges Teachers Are Facing. The International Journal of Special Education, 20(2).

\section{Copyrights}

Copyright for this article is retained by the author(s), with first publication rights granted to the journal.

This is an open-access article distributed under the terms and conditions of the Creative Commons Attribution license (http://creativecommons.org/licenses/by/3.0/). 